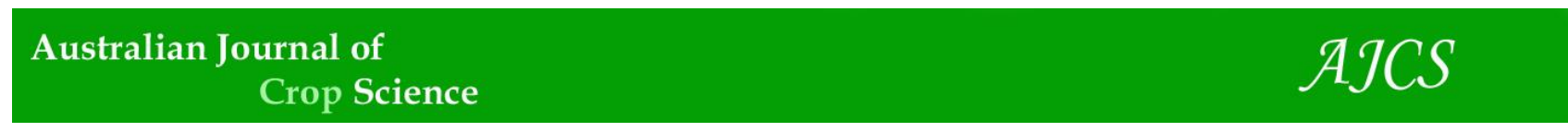

AJCS 13(05):695-700 (2019)

ISSN:1835-2707

doi: 10.21475/ajcs.19.13.05.p1340

\title{
Initial growth of carnauba (Copernicia prunifera) progenies under saline water
}

\author{
Emanuel Lucas Bezerra Rocha, Poliana Coqueiro Dias Araujo*
}

Federal University of the Semi-Arid, Department of Agronomy and Forestry Sciences, Street Francisco Mota, 572,
Costa and Silva, CEP 59625-900, Mossoró, RN, Brazil

*Corresponding author: poliana.coqueiro@ufersa.edu.br

\begin{abstract}
The carnauba (Copernicia prunifera [Miller] H. E. Moore) is a palm tree that has multiple uses and is of great economic and social importance for extractive families in Northeast Brazil. The objective of this work is to analyze the effect of saline water on the production of different progenies of carnauba. The experiment is arranged in a $5 \times 36$ factorial scheme in a randomized complete block design, with five replications and five plants per replication. The treatments consist of five levels of irrigation water salinity (with commercial $\mathrm{NaCl}$ levels, free of iodine: $0,25,50,75$, and $100 \mathrm{mM}$ ) and 36 free-pollination progenies. The following characteristics are evaluated: foliar length $(\mathrm{H})$, collecting diameter (DC), survival rate (TS), number of leaves (NF), dry shoot mass (MSPA), dry mass of the root system (MSSR), and dry mass ratio of the root system to the shoot. The results reveal similar behavior among the progenies for the evaluated characteristics. However, significance is observed for the parameters leaf length, collection diameter, and survival rate when the progenies are subjected to salinity above $9.6 \mathrm{dS} \mathrm{m}^{-1}$. Another significant factor is the accumulation of $\mathrm{Na}^{+}$in the aerial and radicular parts in salinity levels of 7.1,9.6, and $12.0 \mathrm{dS} \mathrm{m}^{-1}$, with the root system being the most affected site. Thus, the tested progenies exhibit similar behaviors in tolerance to irrigation water salinity. Since the carnauba can produce seedlings in water with electrical conductivity of up to $9.6 \mathrm{dS} \mathrm{m}^{-1}$, this species is characterized as a bioindicator of saline soils and is recommended for planting in degraded areas.
\end{abstract}

Keywords: Crop management; Saline stress; Seedling production; Silviculture; Tolerance to salinity.

Abbreviations: $H_{-}$Foliar length; DC_Collecting diameter; TS_Survival rate; NF_ Number of leaves; MSPA_ Dry shoot mass; MSSR_ Dry mass of the root system; CEa _ Electrical conductivity of the irrigation water; CE_ Electrical conductivity; MST_ Total dry mass; MSSR/MSPA_ Dry matter ratio of the root system to the aerial part.

\section{Introduction}

Copernicia prunifera, commonly known as the carnauba, is one of the main economically valuable and drought-resistant palm trees in the Brazilian semi-arid region. Its exploitation is typically carried out by small and medium producers who use mainly the wax from its leaves and also use its stipe, petiole, fruit, and roots (Reis et al., 2011; Vieira et al., 2016). The carnauba has important social value for the populations of Northeast Brazil. It is estimated that more than 200,000 rural producers are economically involved in obtaining wax from carnauba leaves during the dry season, when irregular rains make agricultural plantations unfeasible as sources of income (Ferreira et al., 2013).

In the Brazilian semi-arid region, the carnauba occurs in floodable areas (Rodrigues et al., 2013), including areas of riparian forest. This species is believed to present the characteristics of plants that can grow in environments with high salt concentration (Calheiros et al., 2012), and can therefore be used in forest production and the recovery of areas with salinized soils in the Northeast.

In the northeastern semi-arid region, soil salinization is one of the main causes of yield decline. Intense evaporation and incomplete leaching promote the concentration of salts in soil and surface water (Bui, 2013). In these regions, the salinization of the soil is practically irreversible, since the leaching of accumulated salts is reduced due to the scarcity of freshwater of pluvial or subterranean origin. Soil salinization may also occur from anthropogenic action, which is strongly related to high levels of salts in irrigation water and cultural ill-treatment associated with inadequate drainage and soil management (Plaut et al., 2013).

Salinity can result in physiological drought in a plant from change in osmotic potential. This change reduces the water potential of the substrate and induces a water deficit. Nutritional imbalance due to high ionic concentration leads to antagonistic effects on potassium uptake, water absorption, and enzymatic activity. Salinity also induces sodium and chlorine toxicity (Hasegawa, 2013). The Mimosa caesalpiniifolia Benth and Mimosa ophthalmocentra Mart. Ex Benth are plants native to the semi-arid region. Although they are adapted to the conditions of the Northeast, the two plants do not tolerate soils with a high concentration of salts and osmotic potential of 1.25 and $1.5 \mathrm{dS} \mathrm{ml}^{-1}$, respectively (Leal et al., 2015). However, other Caatinga species may even be favored when exposed to $\mathrm{NaCl}$ concentrations. In 
particular, the Parkinsonia aculeata L. can grow in soils with an osmotic potential of $7.25 \mathrm{dS} \mathrm{ml}^{-1}$ without its development and growth being inhibited. (Bezerra et al., 2013). An understanding of the mechanisms of tolerance and susceptibility to salinity is important for the development of new techniques of crop management that allow for agricultural production under saline stress conditions. Despite the carnauba's considerable potential, research on this species is still incipient.

Therefore, the objective of the present work is to analyze the effect of saline water on the production of half-sib progenies of carnauba seedlings.

\section{Results and discussion}

\section{Growth of carnauba plants under the effects of salinity}

The interaction between the progenies and the salt level was not significant $(p>0.01)$. For the progeny factor as well, no significance was observed for the analyzed variables. This result indicates that these progenies present a similar response to different levels of salinity in irrigation water. However, the salinity of the irrigation water significantly influenced $(p<0.01)$ the leaf length of the different progenies at 30,60, 90, and 120 days after application of the treatments on Copernicia prunifera (Fig 1). Among the applied treatments, T4 and T5 presented a lower average for the evaluated characteristic, presenting reductions of $6.44 \%$ and $14.85 \%$, respectively, in relation to $\mathrm{T} 1$ (Fig 1).

The reduction in leaf length in treatments with higher salinity content may be associated with the stress to which the plants were subjected (Fig 1a). Stress conditions, both water and saline, induce the increase of abscisic acid. Consequently, cell division is inhibited, causing a decrease in leaf length and foliar abscission. This reduces transpiration, which helps lower the absorption of saline water.

A significant influence of salinity on the survival rate (TS) was observed (Fig 1c) on the evaluated days, which included the period from 30 to 120 days. The most negative effects were seen in the T4 and T5 treatments, corresponding to electrical conductivity of 9.6 and $12.0 \mathrm{dS} \mathrm{ml}^{-1}$, respectively. This influence may be associated with high osmotic pressure and the toxic action of elements such as $\mathrm{Na}^{+}, \mathrm{Br}$, and $\mathrm{Cl}$ (Table 1), which reduces the availability of water to the plants, causing physiological disturbances and possible plant-tissue death (Gupta and Huang, 2014).The number of leaves (NF) was not significantly affected $(p<0.01)$ between 30 and 120 days after application of the treatments; therefore, the negative effects of salinity did not influence the addition of leaves when the plants were irrigated with salt water (Fig 1d). In a general analysis of the variables presented in Figure 1, it was inferred that the salinity level significantly affected the T4 and $T 5$ treatments. These differences may be related to the genetic characteristics of the genotypes used in the experiment. After 120 days of evaluation, there was a downward trend for the characteristics evaluated at different levels of salinity (Fig 1). The treatments with higher salinity content, T4 and T5, presented lower means than the others (Fig 1). In general, at 120 days after application of the treatments, the collecting diameter (DC) of the Copernicia prunifera seedlings indicated that the variation in electrical conductivity of the irrigation water (CEa) caused a linear reduction in the size of the seedlings along the evaluation period. Specifically, in the treatments $\mathrm{T} 4$ and T5, the average diameter of the collection of seedlings was estimated to be $5.49 \mathrm{~cm}$ and $5.15 \mathrm{~cm}$, respectively (Fig 1). Similar results were found in a study by Temoteo et al. (2015) while observing different Conilon coffee cultivars. In this study, it was demonstrated that the diameter of the stem was affected by the salinity of the soil as the time of exposure to saline stress increased in the different cultivars and water conditions.

Relative reductions of $8.8 \%$ and $14.6 \%$ were observed when comparing the DC of the plants at 120 days in the T4 and T5 treatments, respectively (Fig 1b). The salinity effect was found to be lower in the collecting diameter (Fig 1b) than in the leaf length (Fig 1a), which demonstrated significant reductions $(p<0.01)$ from treatments T4 and T5, with losses of $6.45 \%$ and $11.76 \%$, respectively. This reduction in seedling growth has also been observed in fruit species, such as in a study by Sousa et al. (2011), which revealed a decrease of up to $70 \%$ when evaluating the initial development of two cashew clones under irrigation with saline water $(0,3.0,6.0$, 9.0 , and $12.0 \mathrm{dS} \mathrm{m}^{-1}$ ). This reduction is due to the early closure of the stomata as a consequence of the change in osmotic potential, which reduces the daily photosynthetic rate. This phenomenon is common in the Brazilian semi-arid region, which has peculiar edaphoclimatic conditions: soils with high concentrations of salts, an environment with a high evaporative demand, and intense solar radiation (Prisco, 1980). Saline stress caused reductions of $3.46 \%$, $5.07 \%, 8.19 \%$, and $14.30 \%$ in total dry mass (Fig 2c) in treatments $\mathrm{T} 2, \mathrm{~T} 3, \mathrm{~T} 4$, and $\mathrm{T} 5$, respectively, in relation to the control (T1). With respect to dry matter of the root system and dry mass of the shoot (Fig 2d), salinity significantly interfered with the value of the SR/PA ratio (Fig $2 \mathrm{~d}$ ) in the T5 treatment, with a reduction of $18.61 \%$, compared to $8.68 \%$ in the 12 treatment. The increase in electrical conductivity of irrigation water is another indication that the root system of the seedlings is most affected by salinity. Furthermore, the leaves are sensitive to high concentrations of salts. This can be interpreted as adaptation of the plant to saline stress. Specifically, the reduction of the leaf transpiration surface is a way to save water when the osmotic potential of the soil solution becomes more negative. This change in osmotic potential occurs as $\mathrm{K}$ reduces because $\mathrm{Na}^{+}$increases in the leaves and roots (Table 1 ) due to difficulty in water absorption (Lima et al., 2015).The reduction of the root system in carnauba seedlings at high levels of salinity may be associated with the physiological mechanism of the carnauba. This mechanism stimulates growth of the aerial part, depending on the type of palm seed, using nutritive reserves in the form of protein bodies and lipids stored in the endosperm (Rodrigues et al., 2013). In addition, the root of the carnauba reaches a depth of $15.5 \mathrm{~cm}$ after 60 days of sowing, potentializing the absorption zone and leading to an increase in leaf area along with a reduction in the effects of physiological drought. The juvenile leaves of carnauba seedlings, which present stomatal indices of $5.18 \pm 0.58$ and $5.17 \pm 0.65$ for the abaxial and adaxial surfaces, respectively, are another factor to be considered. They result in less water loss from perspiration. Even in the treatment with low electrical conductivity (T1), the MSPA was two times higher than that of the root system. Thus, even at high levels of salinity, the carnauba presents a good percentage of survival 
Table 1. Chemical analyses of plant tissue of 36 half-sib progenies of carnauba (Copernicia prunifera) seedlings: PA (aerial) and PR (root) at different salinity levels ( $\mathrm{T} 1=2.0 \mathrm{dS} \mathrm{m}^{-1}, \mathrm{~T} 2=4.6 \mathrm{dS} \mathrm{m}^{-1}, \mathrm{~T} 3=7.1 \mathrm{dS} \mathrm{m}^{-1}, \mathrm{~T} 4=9.6 \mathrm{dS} \mathrm{m}^{-1}, \mathrm{~T} 5=12.0 \mathrm{dS} \mathrm{m}^{-1}$ ) $120 \mathrm{days}$ after application of the treatments (TRAT).

\begin{tabular}{cccccccccccc}
\hline TRAT & LOCAL & $\mathrm{N}$ & $\mathrm{P}$ & $\mathrm{K}$ & $\mathrm{CA}$ & $\mathrm{MG}$ & $\mathrm{FE}$ & $\mathrm{MN}$ & $\mathrm{ZN}$ & $\mathrm{CU}$ & $\mathrm{NA}$ \\
\hline T1 & PA & $19.3 \mathrm{a}$ & $0.85 \mathrm{a}$ & $27.1 \mathrm{a}$ & $5.7 \mathrm{a}$ & $2.2 \mathrm{a}$ & $969 \mathrm{a}$ & $106 \mathrm{a}$ & $36 \mathrm{a}$ & $6.5 \mathrm{a}$ & $5040 \mathrm{a}$ \\
T2 & PA & $24.5 \mathrm{a}$ & $1.27 \mathrm{a}$ & $26.1 \mathrm{a}$ & $6.8 \mathrm{a}$ & $2.6 \mathrm{a}$ & $518 \mathrm{~b}$ & $103 \mathrm{a}$ & $13 \mathrm{~b}$ & $7.0 \mathrm{a}$ & $6552 \mathrm{a}$ \\
T3 & PA & $19.3 \mathrm{a}$ & $0.63 \mathrm{a}$ & $20.5 \mathrm{~b}$ & $4.7 \mathrm{a}$ & $1.8 \mathrm{~b}$ & $593 \mathrm{~b}$ & $48 \mathrm{c}$ & $38 \mathrm{a}$ & $3.5 \mathrm{a}$ & $9071 \mathrm{~b}$ \\
T4 & $\mathrm{PA}$ & $18.4 \mathrm{a}$ & $0.95 \mathrm{a}$ & $20.9 \mathrm{~b}$ & $5.1 \mathrm{a}$ & $1.7 \mathrm{~b}$ & $382 \mathrm{c}$ & $71 \mathrm{~b}$ & $6 \mathrm{c}$ & $6.0 \mathrm{a}$ & $15119 \mathrm{c}$ \\
T5 & $\mathrm{PA}$ & $18.4 \mathrm{a}$ & $0.72 \mathrm{a}$ & $23.7 \mathrm{ab}$ & $4.3 \mathrm{a}$ & $1.5 \mathrm{~b}$ & $210 \mathrm{~d}$ & $81 \mathrm{~b}$ & $1 \mathrm{c}$ & $5.0 \mathrm{a}$ & $13809 \mathrm{c}$ \\
T1 & $\mathrm{PR}$ & $28 \mathrm{a}$ & $2.21 \mathrm{a}$ & $22.9 \mathrm{a}$ & $10.8 \mathrm{a}$ & $4.5 \mathrm{a}$ & $2954 \mathrm{~b}$ & $230 \mathrm{a}$ & $80 \mathrm{a}$ & $21.5 \mathrm{a}$ & $4536 \mathrm{a}$ \\
T2 & PR & $26.7 \mathrm{a}$ & $2.26 \mathrm{a}$ & $10.7 \mathrm{~b}$ & $8.0 \mathrm{a}$ & $4.8 \mathrm{a}$ & $3467 \mathrm{a}$ & $180 \mathrm{~b}$ & $65 \mathrm{ab}$ & $15.5 \mathrm{ab}$ & $6652 \mathrm{a}$ \\
T3 & PR & $14.9 \mathrm{~b}$ & $1.66 \mathrm{a}$ & $8 \mathrm{~b}$ & $10.1 \mathrm{a}$ & $4.3 \mathrm{a}$ & $2927 \mathrm{~b}$ & $218 \mathrm{a}$ & $53 \mathrm{~b}$ & $11 \mathrm{~b}$ & $12801 \mathrm{~b}$ \\
T4 & PR & $21.9 \mathrm{a}$ & $1.55 \mathrm{a}$ & $5.6 \mathrm{~b}$ & $13.0 \mathrm{~b}$ & $4.3 \mathrm{a}$ & $1432 \mathrm{c}$ & $165 \mathrm{~b}$ & $39 \mathrm{c}$ & $6 \mathrm{c}$ & $17941 \mathrm{c}$ \\
T5 & PR & $25.4 \mathrm{a}$ & $1.9 \mathrm{a}$ & $6.4 \mathrm{~b}$ & $14.8 \mathrm{~b}$ & $2.5 \mathrm{~b}$ & $147 \mathrm{~d}$ & $73 \mathrm{c}$ & $39 \mathrm{c}$ & $8.5 \mathrm{bc}$ & $16228 \mathrm{c}$ \\
\hline
\end{tabular}

a)
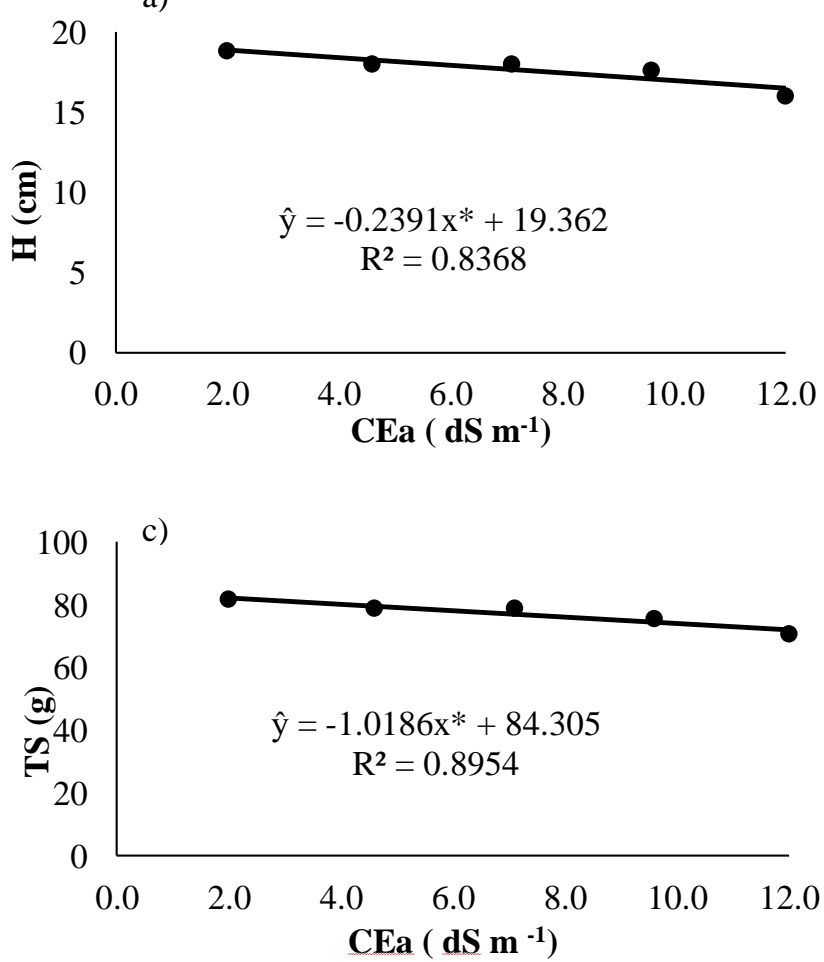

b)

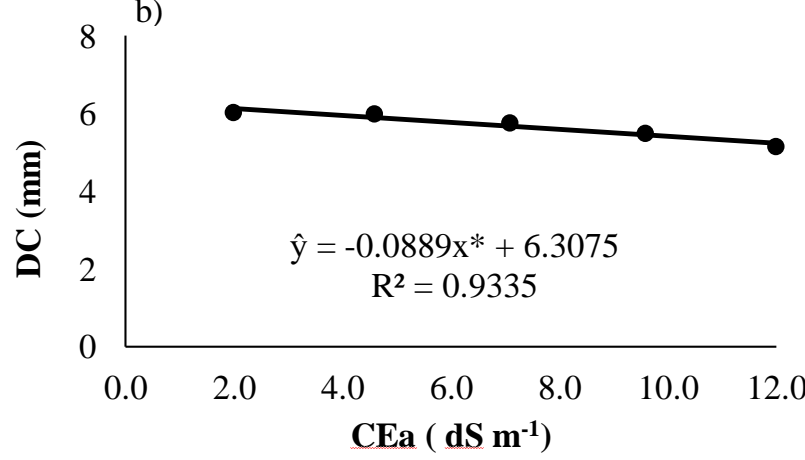

d)

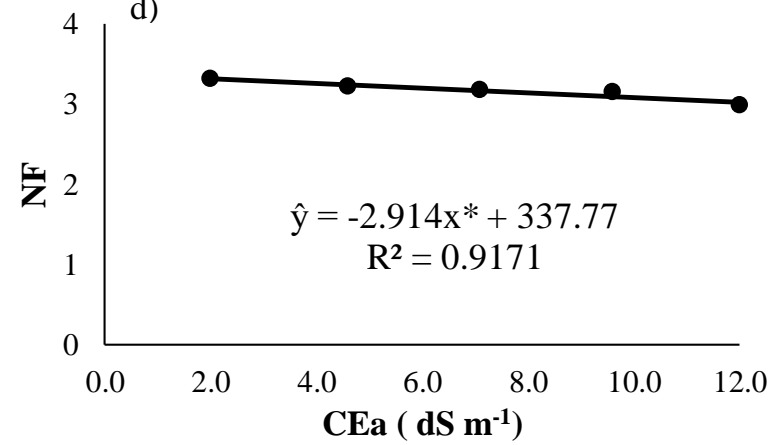

Fig 1. Leaf length (CF-a), collection diameter (DC-b), survival rate (TS-c), and leaf number (NF-d) of 36 half-sib progenies of Copernicia prunifera, as a function of salinity of irrigation water (CEa); $\left(\mathrm{T} 1=2.0 \mathrm{dS} \mathrm{m}^{-1}, \mathrm{~T} 2=4.6 \mathrm{dS} \mathrm{m}^{-1}, \mathrm{~T} 3=7.1 \mathrm{dS} \mathrm{m}^{-1}, \mathrm{~T} 4=9.6 \mathrm{dS}\right.$ $\mathrm{m}^{-1}$, and $\mathrm{T} 5=12.0 \mathrm{dS} \mathrm{m}^{-1}$ ).

(Fig 1c), which may reflect the adaptive characteristics of the species.

\section{Nutrient composition of carnauba plants under the effects of salinization}

Another significant factor $(p<0.05)$ was the accumulation of $\mathrm{Na}^{+}$in the aerial and radicular parts when salinity levels were 7.1, 9.6, and $12.0 \mathrm{dS} \mathrm{m}^{-1}$ (Table 1). The most affected was the root system. An inversely proportional relationship between $\mathrm{Na}^{+}$and $\mathrm{K}^{+}$has been observed that is, as $\mathrm{Na}^{+}$ increases in the plant tissue, $\mathrm{K}^{+}$tends to decrease, because $\mathrm{Na}^{+}$in the tissue competes for the same absorption site as $\mathrm{K}^{+}$, decreasing the absorption of the latter. $\mathrm{K}^{+}$is related to the maintenance of cellular turgor, stretching, opening and closing movements of stomata, tropisms, solute transport in phloem, and energy conservation in membranes (Deinlein et al., 2014; Benito et al., 2014). In addition, the $\mathrm{Na}^{+} / \mathrm{K}^{+}$cell homeostasis is crucial for the plant's survival in saline conditions (Gupta and Huang, 2014; Shabala and Pottosin, 2014). In the root portion, there was a significant increase in Ca content above the salinity level of $7.1 \mathrm{dS} \mathrm{m}^{-1}$ (Table 1). The levels of $\mathrm{Na}^{+}$drove significant increases in $\mathrm{Ca}$ content only in the root portion.

Of the elements studied, $\mathrm{Mg}$ was one of the macronutrients most affected by the $\mathrm{Na}^{+}$increase. Significant salinity effects were seen on the content of $\mathrm{Mg}$ in the aerial and root parts (Table 1). The content of this element was higher in the aerial than in the root part, especially in salinity levels above $4.6 \mathrm{dS} \mathrm{m}^{-1}$. The increase in salinity in the plant is closely 
a)

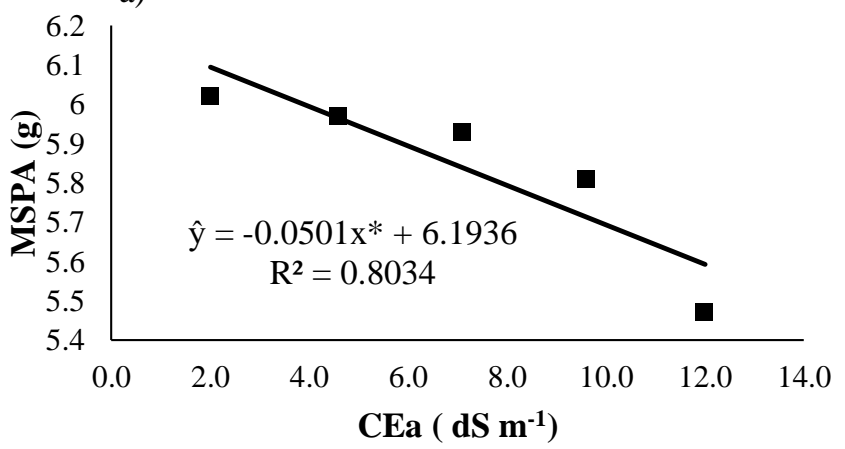

c)

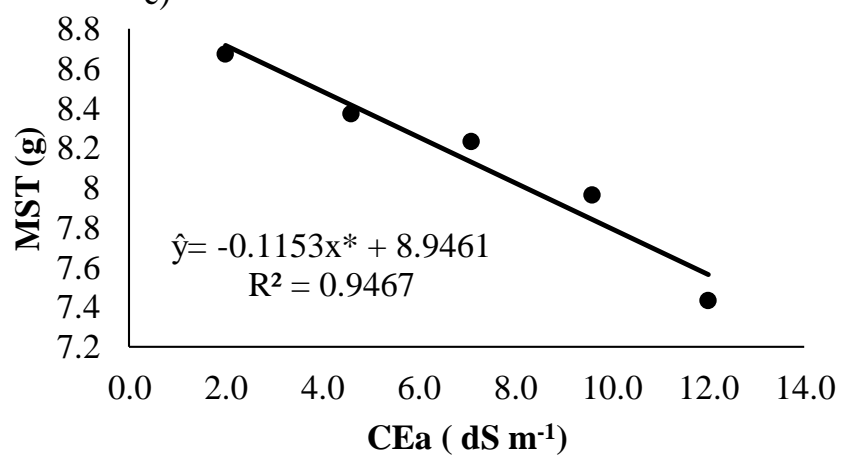

b)

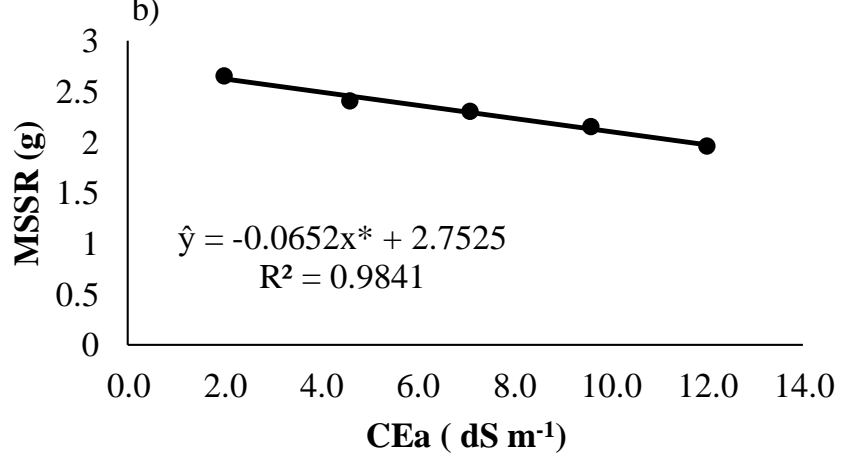

d)

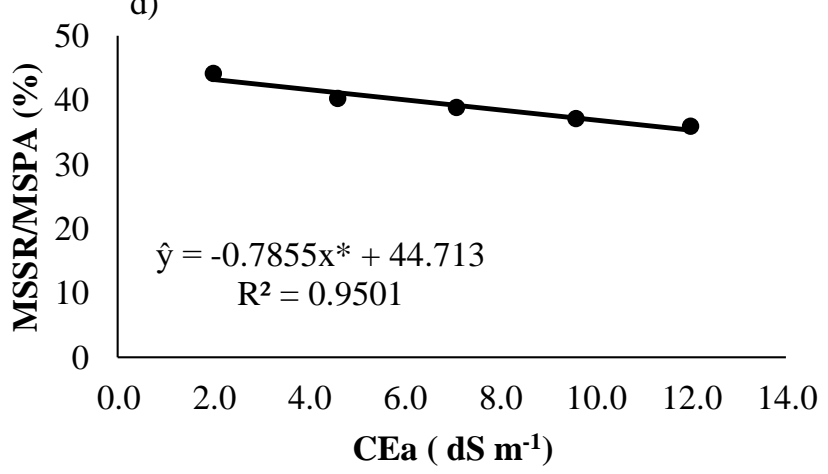

Fig 2. Dry mass of the aerial part (MSPA-a), root system (MSSR-b), total dry mass (MST-c), and dry matter ratio of the root system to the aerial part (MSSR/MSPA-d) of 36 half-sib progenies of Copernicia prunifera, as a function of salinity in irrigation water (CEa), at 120 days after application of the treatments $\left(\mathrm{T} 1=2.0 \mathrm{dS} \mathrm{m}^{-1}, \mathrm{~T} 2=4.6 \mathrm{dS} \mathrm{m}^{-1}, \mathrm{~T} 3=7.1 \mathrm{dS} \mathrm{m}^{-1} ; \mathrm{T} 4=9.6 \mathrm{dS} \mathrm{m}^{-1}\right.$, and T5 $=12.0 \mathrm{dS} \mathrm{m}^{-}$ $\left.{ }^{1}\right)$.

related to the $\mathrm{Na}^{+} / \mathrm{K}^{+}$ratio (Silva et al., 2014). Thus, this relationship is the clearest indicator of sodium toxicity. It promotes an increase in the absorption of the sodium ion to the detriment of potassium absorption, ultimately inhibiting the activity of the enzymes that require potassium. This leads to an ionic imbalance in the plant (Benito et al., 2014). Moreover, salinity impairs plant development by altering its nutrient balance, cellular metabolism, and physiological and chemical processes (Hasanuzzaman et al., 2014; Zia et al., 2011). These changes result in morphological adaptations so that the carnauba can tolerate the stress. Thus, during the course of the experiment, the extent to which the exposure of the seedlings to saline stress exceeded the tolerance of the plant was observed. They developed modifications such as burns and necroses, falling of thorns, and chlorosis along and tortuosities in the leaves. These modifications reduced the growth and sometimes caused the death of the young plant (Jindal et al., 1976; Maeda et al., 2010; Oliveira et al., 2012). This explains the significant reduction in growth of

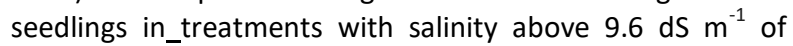
electrical conductivity (Fig 1).In general, this study reveals that the carnauba tolerates a salinity level of $9.6 \mathrm{dS} \mathrm{m}^{-1}$. The tolerance limit is an excellent primary bioindicator of soils with high saline concentrations that change according to variations in the environment. This value is higher than that found by Holanda et al. (2011), who studied the same species subjected to saline stress and demonstrated that the development of the carnauba was compromised in concentrations greater than or equal to $3 \mathrm{dS} \mathrm{m}^{-1}$. These authors studied the carnauba for up to 120 days after sowing. However, in the present study, salinity started to have an effect after 120 days of sowing. Thus, it is evident that phenology influences the salinity tolerance of the carnauba.

The tolerance of the carnauba to salinity of irrigation water during the production of seedlings may also be associated with genetic differences within the species. According to Gupta and Huang (2014), genetic variations exist in tolerance to salt in irrigation water and in the soil, and the degree of tolerance varies among species and plant varieties within a species. This finding was confirmed by Fernandes et al. (2011) when they studied the sensitivity of different varieties and hybrids of lemon trees tolerant to saline conditions.

\section{Materials and methods}

\section{Plant materials}

The experiment was conducted at the seedling production nursery of Federal University of the Semi-Arid, Mossoró, Brasil. For producing the seedlings and establishing the experiment, 36 matrices were selected based on the natural survival capacity of the carnauba in saline soils. Thus, 9 matrices were selected in four populations established in salinized areas, and the experiments were conducted with the free-pollination progenies of these matrices. The seeds used were obtained from fruits with yellow-green coloration collected during the maturation stage. These fruits were packed in plastic bags and transported to the post-harvest laboratory, where they were stored. 


\section{Conduction of study}

The seeds were subjected to the pre-soaking process in plastic bottles, where they remained for the time necessary for protrusion of the cotyledonary petiole. After this, 15 seeds were selected from each lot for sowing, standardized by cotyledonary petiole length $(4 \mathrm{~mm})$. The pre-germinated seeds were sown horizontally at a depth of $2 \mathrm{~cm}$, three seeds per bag of polyethylene with a capacity of $1 \mathrm{~L}$, filled with organic substrate and exposed daily to irrigation with natural tap water.

Following germination, the plants were watered daily with tap water for 180 days. After this period, irrigation treatments were started that consisted of the following levels of commercial $\mathrm{NaCl}$ free of iodine: $0,25,50,75$, and $100 \mathrm{mM}$ (CE) of 2.0, 4.6, 7.1, 9.6, and $12.0 \mathrm{dS} \mathrm{m-1}$, respectively.

The seedlings were watered daily at the same time for 120 days with the same amount of solution, $100 \mathrm{ml}$. To prepare the solutions for each treatment, besides the amount of water in each vessel, the atomic weight of $\mathrm{NaCl}$ was also considered.

\section{Experimental design}

The experiment was conducted in a $5 \times 36$ factorial design, comprising 5 treatments of salinity and 36 progenies, at the randomized complete block design with five replications. The experimental units consisted of five plants.

\section{Traits measured}

To comprehensively analyze the effect of different salt concentrations, at the end of the experiment, we evaluated leaf length (CF), collecting diameter (DC), survival rate (TS), number of leaves (NF), dry shoot mass (MSPA), dry mass of the root system (MSSR), total dry mass (MST), and dry matter ratio of the root system to the aerial part (MSSR/MSPA), in accordance with Benicasa (1988). The variables were observed $30,60,90$, and 120 days after application of the treatments. Chemical analysis of the plants (N, P, K, Ca, Mg, Fe, Mn, $\mathrm{Zn}, \mathrm{Cu}$, and $\mathrm{Na}$ ) was also conducted.

\section{Statistical analysis}

Variances and means were analyzed for the data obtained from the evaluations by performing the ANOVA one-way test followed by Tukey's post-test at $1 \%$ probability in the statistical program Prisma ${ }^{\circledR}$. Additionally, for the variables CF, DC, TS, NF, MSPA, MSSR, MST, and MSSR/MSPA at 120 days, regression analyses were performed and equations of linear models obtained.

\section{Conclusion}

The progenies tested demonstrated similar behavior related to tolerance to salinity of irrigation water. They displayed potential for the production of seedlings in water with electrical conductivity of up to $9.6 \mathrm{dS} \mathrm{m}-1$. This species can therefore be characterized as a saline soil bioindicator and is recommended for recovery of degraded areas with high salt levels.

\section{Acknowledgements}

The authors thank the National Council for Scientific and Technological Development (Conselho Nacional de Desenvolvimento Científico e Tecnológico - CNPq).

\section{References}

Benito B, Haro R, Amtamann TAC, Dreyer I (2014) The twins $\mathrm{K}+$ and $\mathrm{Na}+$ in plants. J Plant Physiol. 171:723-731.

Benicasa MMP (1988) Análise de crescimento em plantas (noções básicas). Jaboticabal, UNESP. 42

Bezerra FTC, Andrade LA, Cavalcante LF, Pereira WE, Bezerra MAF (2013) Emergência e crescimento inicial de plantas de Parkinsonia aculeata L. (Fabaceae) em substrato salino. Rev Árvore. 37(4):611-618.

Bui EN (2013) Soil salinity: a neglected factor in plant ecology and biogeography. J Arid Environ. 92:14-25.

Calheiros CSC, Quitério PVB, Silva G, Crispim LFC, Brix H, Moura SC, Castro PML (2012) Use of constructed wetland sytens with arundo and sarcocomia for polishing high salinity tannery waste water. J Environ Manage. 95:66-71.

Deinlein U, Stephan AB, Horie T, Luo W, Xu G, Schroeder JI (2014) Plant salt-tolerance mechanisms. Trends Plant Sci. 6:371-9.

Fernandes PD, Brito MEB, Gheyi, HR, Soares Filho WdosS, Melo ASde, Carneiro PT (2011) Crescimento de híbridos e variedades porta-enxerto de citros sob salinidade. Acta Sci Agron. 33(2):259-267.

Ferreira CdaS, Nunes JAR, Gomes RLF (2013) Manejo de corte das folhas de Copernicia prunifera(Miller) H. E. Moore no Piauí. Rev Caatinga. 26(2):25-30.

Hasanuzzaman M, Alam MM, Rahman A, Nahar K, Fujita M (2014) Exogenous proline and glycine betaine mediated upregulation of antioxidant defense and glyoxalase systems provides better protection against saltinduced oxidative stress in two rice (Oryza sativa L.) varieties. Biomed Res Int. 1:1-17.

Hasegawa PM (2013) Sodium ( $\mathrm{Na}+$ ) homeostasis and salt tolerance of plants. Environ Exp Bot. 92:19-31.

Holanda, SJR, Araújo FSde, Gallão MI, Medeiros FS (2011) Impacto da salinidade no desenvolvimento e crescimento de mudas de carnaúba (Copernicia prunifera (Miller) H.E.Moore). Rev Bras Eng Agríc Ambient. 15(1):47-52.

Jindal PC, Singh JP, Gupta OP (1976) Studies on salt tolerance in mango-injurious effects of salt on young mango seedlings. Prog Hort. 8(1):65-71.

Lima LA, Oliveira FdeAsde, Alves RdeC, Linhares PSF, Medeiros AMAde, Bezerra FMS (2015) Tolerância da berinjela à salinidade da água de irrigação. Rev Agroamb. 9(1): 27-34.

Leal CCP, Torres SB, Nogueira NW, Freitas RMO, Farias RM (2015) Emergence and early development of seedlings of Mimosa ophthalmocentra irrigated with brackish water. Biosci J. 31(3):759-766.

Maeda S, Silva HD, Bellote AFJ (2010) Efeito da salinidade em características biométricas e na nutrição de Pinus taeda em neossolo litótico húmico. Pesq Flor Bras. 30(61):51-59.

Oliveira FdeA, Oliveira FRA, Campos MdeS, Oliveira MKT, Medeiros JF, Silva OMdosP (2010) Interação entre salinidade e fontes de nitrogênio no desenvolvimento 
inicial da cultura do girassol. Revi Bras Cien Agr. 5(4):479484.

Plaut Z, Edelstein M, Ben-hur M (2013) Overcoming salinity barriers to crop production using traditional methods. Crit Rev Plant Sci. 32: 250-291.

Prisco, J. T. (1980) Alguns aspectos da fisiologia do "stress" salino. Rev Bras Bot. 3:85-94.

Reis, RdeGE, Pereira MS, Gonçalves NR, Pereira DS, Bezerra AME (2011) Emergência e qualidade de mudas de Copernicia prunifera em função da embebição das sementes e sombreamento. Rev Caatinga. 24(4):43-49.

Rodrigues LC, Silva AA, SilvA RB, Oliveira AFM, Andrade LHC (2013) Conhecimento e uso da carnaúba e da algaroba em comunidades do sertão do Rio Grande do Norte, nordeste do Brasil. Rev Árvore. 37(3):451-457.

Shabala S, Pottosin I (2014) Regulation of potassium transport in plants under hostile conditions: implications for abiotic and biotic stress tolerance. Physiol Plant. 151:257-279.
Silva IP, Rodas CL, Ferreira ED, Carvalho J G (2014) Crescimento e nutrição de mudas de pinhão-manso influenciados pela substituição do potássio pelo sódio. Rev Caatinga. 27(1):194-199.

Sousa ABO, Bezerra MA, Farias F (2011) Germinação e desenvolvimento inicial de clones de cajueiro comum sob irrigação com água salina. Rev Bras Eng Agríc Ambient. 15(4):390-394.

Temoteo AdaS, Sousa AdeP, Santos CMdos, Teramoto ET (2015) Crescimento de cultivares de cafeeiro conilon submetidas ao estresse salino-hídrico. Rev Caatinga. 28(2):46-56.

Vieira IR, Oliveira JS, Verola CF, Loiola MIB (2016) Traditional knowledge, use, and management of Copernicia prunifera H. E. Moore (carnaúba) in Northeastern Brazil. Esp. 37(8):18.

Zia A, Guo B, Ullah I, Ahmad R, Khan MA, Abbasi BH, Wei Y (2011) Salinity tolerance and site of $K+$ accumulation in four maize varieties grown in Khyber Pakhtoonkhwa region of Pakistan. J Med Plants Res. 5(25):6040-6047. 